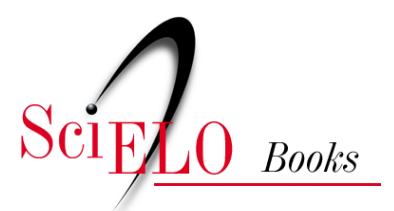

\title{
Formação de capital
}

\author{
José Carlos Radin \\ Gentil Corazza
}

\section{SciELO Books / SciELO Livros / SciELO Libros}

RADIN, J.C., and CORAZZA, G. Formação de capital. In: Dicionário histórico-social do Oeste catarinense [online]. Chapecó: Editora UFFS, 2018, pp. 75-78. ISBN: 978-85-64905-65-8. https://doi.org/10.7476/9788564905658.0017.

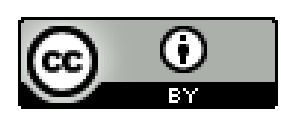

All the contents of this work, except where otherwise noted, is licensed under a Creative Commons Attribution 4.0 International license.

Todo o conteúdo deste trabalho, exceto quando houver ressalva, é publicado sob a licença Creative Commons Atribição 4.0.

Todo el contenido de esta obra, excepto donde se indique lo contrario, está bajo licencia de la licencia $\underline{\text { Creative Commons }}$ Reconocimento 4.0. 


\section{Formação de capital}

A formação/acumulação inicial de um estoque de capital é de fundamental importância para o desenvolvimento econômico e social de uma região. A origem e a evolução histórica da formação/acumulação de capital variam de acordo com a situação e as circunstâncias históricas de cada região. Não há um padrão universal que se repete em todos os tempos e lugares.

No Oeste catarinense, a formação/acumulação de capital se deu progressivamente a partir da evolução das atividades econômicas que ali se desenvolveram. De certa forma ela acompanha a sucessão dos ciclos econômicos, que marcam a história desta região, de acordo com a importância relativa de cada um deles na economia regional.

Por razões diversas, os três primeiros ciclos, o da pecuária, da erva-mate e da madeira, pouco contribuíram para a formação inicial do capital da região. O início deste processo de acumulação de capital só aconteceu a partir do projeto de colonização, onde se desenvolveram a agricultura familiar e a criação de suínos com fins comerciais. A formação do capital comercial e sua posterior transformação em capital industrial comandaram o processo de desenvolvimento da região Oeste catarinense. Foi a partir da agricultura familiar, especialmente através da criação e comercialização de suínos, que se formou o capital comercial, fonte da acumulação inicial e do desenvolvimento capitalista da região. Antes da criação e comercialização de suínos, nem as atividades da pecuária ou as da erva-mate, nem mesmo a indústria madeireira, foram fontes de acumulação de capital para a região, exceção feita a algumas pequenas serrarias, ali instaladas, mais com o objetivo de suprir as necessidades locais dos colonos do que para fins comerciais. Já as grandes madeireiras desmatavam e beneficiavam a madeira, visando unicamente sua exportação e, do mesmo modo que a madeira, também enviavam seus lucros para fora da região, deixando de contribuir para o seu desenvolvimento econômico. Em algumas colônias, sobretudo alemãs, a cultura do fumo teve papel importante na formação de uma renda extra para os agricultores. 
Mas o capital começou mesmo a ser acumulado a partir da venda de terras pelas companhias colonizadoras e especialmente da criação e do comércio de suínos pelos colonos procedentes do Rio Grande do Sul (GOULARTI FILHO, 2007).

Foi no âmbito da agricultura familiar que a criação de suínos se afirmou com grande potencial de desenvolvimento. Aos poucos, essa atividade foi deixando de produzir apenas para a subsistência dos colonos e se transformou na sua principal atividade comercial. Embora o objetivo maior fosse a produção para o autoconsumo familiar, a comercialização do excedente colonial, agrícola e pecuário se desenvolve de modo que aos poucos a produção para o comércio foi se tornando dominante e se afirmando como um novo e principal objetivo da produção agrícola familiar.

Inicialmente, os agricultores criavam suínos comuns, tipo banha, soltos, alimentados com produtos oriundos da propriedade do agricultor, cujo abate se dava, em média, após quatorze meses de vida. A produção da banha suína, e não a da carne, devido as suas peculiaridades de conservação, foi se transformando num dos principais produtos de valor comercial capaz de gerar alguma renda excedente ao consumo para colonos e comerciantes. Sua produção alimentava uma rede de comercialização formada pelas casas comerciais situadas em pontos-chave das áreas coloniais da região. Depois, progressivamente, foram sendo introduzidas novas raças, cuja criação exigia dos agricultores um novo padrão técnico, como o confinamento dos animais, maiores cuidados sanitários, rações mais elaboradas, o que acarretou o aumento de produtividade. Assim, o período de terminação dos suínos foi se encurtando progressivamente até chegar à média atual de apenas seis meses.

Nos primeiros tempos, ainda na década de 1930, algum excedente dessa produção começava a ser comercializado nas "vendas", ou pequenas casas comerciais da região, mas, à medida que o excedente passou a ser mais expressivo, sua comercialização se amplia para além do pequeno comércio local, atingindo outros centros consumidores do país, como São Paulo, Rio de Janeiro e Rio Grande do Sul. Os comerciantes ampliam suas compras dos agricultores, fornecendo em 
troca produtos mais elaborados, como tecido em metro, querosene, sal, ferramentas agrícolas e outros produtos industrializados, criando-se uma maior relação de dependência entre agricultores e comerciantes. Com o desenvolvimento do comércio, amplia-se também o papel econômico-comercial, comunitário e mesmo político do comerciante. Aos poucos, ele vai se tornando uma figura indispensável para o desenvolvimento das atividades econômicas da região. Efetivamente, a partir de suas atividades comerciais, o comerciante tinha uma grande ascendência sobre os colonos, dado seu poder de persuasão e seu maior conhecimento sobre os mais variados temas, que iam desde a prática agrícola, à economia financeira e, também, sobre a orientação político-partidária.

É através desse processo que o desenvolvimento do capital comercial vai provocar sua própria transformação em capital industrial, à medida que começa a ser investido no abate dos animais e no processamento da carne suína. Inicialmente, o suíno era levado vivo para São Paulo. Mas, na medida em que este comércio deixou de ser rentável, foram gradativamente surgindo pequenos abatedouros locais destinados à produção e comercialização da carne suína. Nos anos 1940 e 1950, esses abatedouros vão se transformando em pequenos frigoríficos dedicados, primeiro, ao processamento da banha e, depois, com a chegada da luz elétrica e as câmaras frigoríficas, passam também a processar a carne suína (MIOR, 2005). Foi assim, a partir do capital comercial, coadjuvado pela renda dos pequenos agricultores, que se formaram os primeiros abatedouros e frigoríficos, através dos quais se deu a transformação do capital comercial em capital industrial. Nesse processo de transformação, aos poucos, com o desenvolvimento dos próprios frigoríficos, tanto comerciantes como agricultores vão se tornando figuras secundárias, até desaparecerem completamente com a estruturação do complexo frigorífico e agroindustrial da região. Por algum tempo, ainda, o comerciante continua como responsável pela coleta e transporte dos suínos, enquanto o frigorífico se ocupa do abate e da venda da produção. E os pequenos agricultores, que, de início, entraram como sócios ou acionistas dos frigoríficos, aos poucos vão sendo excluídos, à medida que o valor de suas cotas de participação 
foi se tornando insignificante. Em um determinado momento, o frigorífico torna-se uma empresa capitalista e o empresário industrial se torna seu único proprietário.

\section{REFERÊNCIAS}

CAMPOS, Índio. Os colonos do Rio Uruguai: relações entre pequena produção e agroindústrias no oeste catarinense. Campina Grande UFPB, 1987 (Dissertação de mestrado).

COLETTI, Tomé. Agroindústria suinícola e agricultura familiar: uma "crônica" sobre a trajetória histórica no Oeste Catarinense. (Dissertação de Mestrado) Florianópolis: UFSC, 2009.

GOULARTI FILHO, Alcides. A Estrada de Ferro São Paulo-Rio Grande na formação econômica regional em Santa Catarina. Florianópolis, Geosul, V. 24, N. 48, 2009.

. Formação Econômica de Santa Catarina. Florianópolis: UFSC, 2007.

MIOR, Luiz Carlos. Agricultores familiares, agroindústrias e redes de desenvolvimento rural. Chapecó: Argos, 2005. 